\title{
Plasma Levels of Phospholipids in Patients With COVID-19; A Promising Simple Biochemical Parameter to Evaluate the Disease Severity
}

Mohammed Abdalla ( $\sim$ prof.husseinma@o6u.edu.eg)

October 6 University https://orcid.org/0000-0002-1811-2794

Noor Eldin Mohamed Ismail

2Chest diseases consultant, Shobra health insurance hospital, Shobra, Egypt.

ahmed $\mathrm{h}$ mohamed

Department of Radiology and Medical Imaging, Faculty of Applied Medical science, October 6th University, October 6th City, Egypt.

Rita M Borik

Chemistry Department, Faculty of Science (Female Section), Jazan University, Jazan 82621, Saudi Arabia

Ali a ali

Vice president of post graduate studies, October 6 University, Sixth of October City, Egypt.

Yasser 0 Mosaad

Department of Pharmacy Practice \& Clinical Pharmacy, Faculty of Pharmaceutical sciences \& Pharmaceutical Industries, Future University.

\section{Research}

Keywords: COVID-19 pandemic, phospholipids, pulmonary surfactant, sPA2 and cytokine storm

Posted Date: August 19th, 2020

DOI: https://doi.org/10.21203/rs.3.rs-57302/v1

License: (c) (i) This work is licensed under a Creative Commons Attribution 4.0 International License. Read Full License 


\section{Abstract}

Background Cronavirus-19 (COVID-19) pandemic is a worldwide public health problem knowing in China recently from December 25, 2019. Phospholipids are structural components of mammalian cytoskeleton and cell membranes. Phospholipids is an anionic lipid found in mammalian membranes in low amounts $(1-2 \%)$ of the total phospholipids. Also, it suppressed viral attachment to the plasma membrane and subsequent replication in lung cells.

Aim: The present study was carried out to explain the correlation between the plasma phospholipids as well as secretory phospholipase-A2a2 (sPLA2a2) and cytokine storm; tumor necrosis factor (TNF)-a, interleukin-1 $\beta$ (IL-1 $\beta$ ), interleukin-6 (IL)-6 and interleukin-13 (IL-13_ levels of patients with COVID-19 to assess the infection severity.

Methods: Serum samples from enrolled 34 patients with mild, moderate, and acute COVID-19 infection. Complete blood picture (CBC), plasma d-dimer, ferritin, C-reactive protein (CRP), lipid profile, phospholipids, sPLA2 $\alpha 2$ and TNF-a, IL-1 $\beta$, IL- 6 and IL-13 as well as lung computed tomography (CT) imaging.

Results: CBC showed that the presence of leukopenia, lymphopenia, eosinopenia in patient with mild, moderate, and acute COVID-19 infection. Also, significant increase in plasma d-dimer, CRP, ferritin, triacyclglycerols, TNF-a, IL-1 $\beta$, IL- 6 and IL-13 levels as well as SPLA2 2 2 activity when compared to normal persons. However, plasma levels of phospholipids, cholesterol, HDL-C and LDL-C were decreased significantly in patient with acute COVID-19 infection only, when compared to normal persons. In addition, lung computed tomography (CT) scan showed that the presence of ground glass opacity (GGO), bronchial wall thickening, crazy paving sign as well as right, left, upper and lower lung predominant in patient with mild, moderate and acute COVID-19 infection. The levels of blood leukopenia, lymphopenia and eosinopenia as well as plasma phospholipids d-dimer, CRP, ferritin, cytokine storm and SPLA2a2 were pronounced in group of patients with acute COVID-19 infection more the mild and moderate one.

Conclusion: The present study was showed that there is a correlation between plasma phospholipids depletion as well as elevation sPLA2a2 and cytokines storm with the severity of COVID-19 infection. Also, the plasma phospholipids levels can used to estimate COVID-19 infection severity and help to identify patients into three classes: mild, moderate and severe one.

\section{Introduction}

Coronavirus disease (COVID-19) is a recently discovered infectious disease [1]. Most patients with COVID19 infection will experience mild to moderate breathing problems and recover without specific treatment [2]. Also, COVID-19 represents a spectrum of clinical severity ranged from asymptomatic to critical pneumonia, acute respiratory distress syndrome (ARDS) and even death [3]. The Coronavirus-2 mainly spreads by droplets of saliva or nose discharge when an infected person coughs or sneezes, so it's important that you also practice respiratory etiquette [5]. 
Till July 13, 2020, Coronavirus infected cases; $13,134,673$ and 83,001 deaths; 573,302 and 3,935; recovered; 7,659,360 and 24,975, Worldwide and Egypt, respectively [5, 6]. It seems there are no clear vaccines or therapies for COVID-19. However, there are several clinical trials which test alternative therapies [7].

Accumulating evidence suggests inflammatory mediators play a crucial role in COVID-19 $[8,9]$. Inflammatory responses caused by SARS-CoV-2 replication lead to cell destruction and macrophages as well as cytokine release [10].

Multiple inflammatory markers identify and detect specificity for the fatality of diseases [11]. It has been documented that inflammatory markers such as procalcitonin (PCT), serum ferritin, erythrocyte sedimentation rate (ESR), C-reactive protein (CRP) and interleukin-6 (IL-6) are significantly associated with the high risk of developing extreme COVID19 [11-14]. In addition, it is shown that increased levels of serum amyloid $A$ (SAA) are involved in COVID-19 pathogenesis and may be potential biomarker for disease progression monitoring $[15,16]$.

The pulmonary surfactant is a unique combination of phospholipids, neutral lipids and proteins [17]. Several institutional entities make it represented; Lamellar plates, myelin tubular and a monolayer [18]. Lung surfactant has shown to exist in all air-breathing vertebrates, though composition can vary through species [19].

Phospholipids are the primary components of the pulmonary surfactant, with phosphatidylcholines (PCs) as the dominant compound. Dipalmitoyl-PC is the most abundant lipid molecular species in surfactant and the most responsible lipid for reducing surface tension within the alveolar compartment at the airtissue interface [20]. In humans, palmitoyl-oleoyl-PG (POPG) is the most abundant molecular species present within the PG class [21] that suppresses LPS-induced inflammatory responses in vivo and in vitro through direct interactions with certain cell receptors [22]. Other lipids are phosphatidylglycerol (PG), phosphatidylethanolamine (PE), phosphatidylinositol (PI), phosphatidylserine (PS), sphingomyelin, cholesterol, triacylglycerols and free fatty acids [23]. The PC molecule comprises a glycerol backbone, two fatty acids, phosphate, and a choline moiety. Approximately $60 \%$ of the PC contains two saturated fatty acids (sat PC, DSPC) of which most is dipalmitoyl (16:0/16:0) (DPPC). DPPC is the principal surface tension lowering component of surfactant. Most other PC molecules have a fatty acid with one double bound in the 2 position of the glycerol molecule. Four surfactant proteins have been identified [24].

Recently, Hussein [25] reported that, over expression of cPLA2 caused by COVID-19 infection lead to phosphatidylglycerol depletion and cleavage of fatty acids esterified as well as enhance inflammation and lung damage.

Also, secretory phospholipase A2 (sPLA2) is involved in eicosanoid synthesis [26], maturation and migration of dendritic cells [27, 28],T cell proliferation [29] as well as cytokine and chemokine production by monocytes, macrophages, neutrophils and eosinophils [30-33]. 
In this case, COVID-19 infection induces many pro-inflammatory cytokines, including TNF, interferon- $\gamma$, IL1, IL-6, IL-18, and IL-33, to secret in an unrestrained way causing a cytokine storm [34].

Cytokines are known to play a major role in lung injury and repair and are essential for fibrosis pathogenesis. Some of them tend to be involved in local injury and inflammatory reaction (IL-1, IL-8, TNFalpha), while others are involved in repair and fibrosis of the tissue (PDGF, IGF-1, TGF- $\beta$ ). Cytokines form complex networks, coordinated by key cytokines, and the most important feature in understanding fibrosis pathogenesis appears to be the balance of positive (profibrogenic) and negative (antifibrogenic) forces produced by interactions between the different cytokines [35].

TNF- alpha is exerted as a potent stimulus in inflammatory responses through upregulation of cPLA2 gene expression [36, 37].

We here hypothesized that plasma level of phospholipids will change during COVID-19 infection and can be used to monitor illness. We sought to elucidate the relations between plasma phospholipids levels and sPLA2 gene expression as well as cytokines storm in patient with COVID-19 infection.

\section{Materials And Methods}

\section{Study population}

In this prospective non-randomized study, we enrolled 45 males with average age $40-45$ years, COVID19 suspicion at Shobra health insurance hospital, Egypt.

According to the results of biochemical and radiological examination, they are classified as the follow:

Group 1 (negative COVID-19): 11 persons with normal BP $(120 / 80 \mathrm{mmHg})$ and healthy hemodynamic and biochemical parameters were recruited in our study as a healthy control group.

Group 2: 15 patients with mild COVID-19 infection.

Group 3: 10 patients with Moderate COVID-19 infection.

Group 4: 9 patients with acute COVID-19 infection.

On the other hand, the study protocol was approved by the local ethics committee of Shobra health insurance hospital, Egypt.

Patients should be considered for COVID-19 testing have a significant respiratory illness: fever with dry cough, fatigue or difficulty breathing and were tested using COVID-19 IgG/IgM Rapid Test Kit, Abbexa, Cambridge, United Kingdom) as well as lung CT using syngo. CT DE Lung Analysis - Siemens Healthineers Global, Germany. 
Healthy participants were recruited under the conditions of a free routine health examination. All participants in this study satisfied the following inclusion criteria: i) Proven diagnosis of COVID-19 infection or benign disease by Prof Dr. Noor Eldin Mohamed Ismail, Chest diseases consultant, Shobra health insurance hospital; ii) no adjuvant therapy or surgery prior to blood sample collection from persons with negative test of COVID-19 infection as well as patients with positive test of COVID-19 infection; iii) Exclusion criteria included presence of autoimmune disease, acute kidney injury or with unsatisfactory vascular access or any other known condition that would alter cytokines as well as phospholipids levels. Moreover, none of our patients had received antibiotics, anti-inflammatory or corticosteroid medications during the study period. The present study was reviewed and approved by the ethics committee of Shobra health insurance hospital.

Clinical assessments included complete history taking, past medical and disease history for confirming the appropriateness of the patients to the inclusion criteria. BP and MBI monitoring were according to the international guidelines.

\section{Blood sampling and Biochemical analyses}

Venous blood samples $(4 \mathrm{~mL})$ were obtained from all persons with negative test of COVID-19 infection as well as patients with positive test of COVID-19 infection and were divided into two aliquots: one aliquot was anticoagulated and divided into 2 test tubes; the first one for haematological examinations of total erythrocyte count (TEC), haemoglobin ( $\mathrm{Hb}$ ), mean cell volume (MCV), mean corpuscular haemoglobin concentration (MCHC), and total leukocyte, lymphocyte, eosinophil and monocyte counts using a Hema Screen 18-Automated Haematology Analyser (Hospitex Diagnostics, Sesto Fiorentino, Italy). The second test tube, plasma separated for D-dimer with an Sysmex ${ }^{\circledR}$ CA-7000 system coagulation analyzer (Sysmex, Kobe, Japan), and detection of hs-CRP with a Hitachi Model 7600 Series Automatic Analyzer (Hitachi High Technologies Corporation, Hitachi, Japan).The kits used in the experiments were D-dimer PLUS (Simens Healthcare Diagnostics Products $\mathrm{GmbH}$ ) and Reagent kit for hs-CRP test (latex agglutination assay). Their reference values were 0.1417 (90\% CL 0.00-0.55) $\mu \mathrm{g} / \mathrm{ml}$ for $\mathrm{D}$-dimer, and $<6$ $\mathrm{mg} / \mathrm{L}$ for hs-CRP, respectively.

From other aliquot of blood, samples were allowed to clot, and sera were then separated by centrifugation (3500 rpm, $20 \mathrm{~min}, 25^{\circ} \mathrm{C}$ ) was stored at $-20^{\circ} \mathrm{C}$ for later biochemical determinations. Plasma levels of total cholesterol, HDL-C, triacyclglycerols and phospholipids were estimated using Synchron cx 5 autoanalyzer (Beckman, USA) and LDL-cholesterol levels were calculated by using the Friedewald formula. Also, proinflammatory markers such as tumor necrosis factor (TNF)-a, interleukin (IL)-1 $\beta$, interleukin (IL)- 6 and interleukin IL-13 assessment using commercially available enzyme-linked immunosorbent assay kits (R\&D Systems Inc., Minneapolis, MN, USA). Serum iron was determined by the bathophenanthroline method (American Monitor Corporation; Indianapolis, IN). Serum ferritin was quantitated using the Enzyme Linked Fluorescent Assay technique. (VIDAS® Ferritin, bioMérieux SA, France).

Plasma SPLA2 activity was assayed according to the method adapted by Petrovic [38] using spectrophotometer (Molecular Devices, Sunnyvale, California, USA) at absorbances 425 and $600 \mathrm{~nm}$. 


\section{Statistical analysis}

All data were expressed as mean \pm SD. All analyses utilized SPSS 15.0 statistical package for Windows (SPSS Inc., Chicago, IL). A one-way analysis of variance (ANOVA) was employed for comparisons of means of the different groups. A p-value $<0.05$ was accepted as statistically significant with LSD test as the post -hoc test. Spearman rank correlation test was used for the assessment of correlation. The statistical significance was accepted as $P$ value $<0.05$.

\section{Results}

Table 1 showed some hematological parameters of patients with COVID-19 compared to negative persons. All patients in groups (2-4) had a normal CBC (normal Hb, RBCs, MCV, MCH and MCHC) and non-significant change when compared with persons with negative test of COVID-19 infection (Group 1). Also, platelet count of patients with COVID-19 (groups 2-4) was significant decreased $(p<0.05)$ when compared with persons with negative test of COVID-19 infection (Group 1). Also, patient with acute COVID-19 infection having mild thrombocytopenia (platelet count $140 \times 10^{9} / \mathrm{L}$ ).

On the other hand, mild, moderate and sever leukopenia was observed in patients with COVID-19 infection (Groups 2-4) with WBC $\left(5.00 \times 10^{3} / \mathrm{L}, 4.00 \times 10^{3} / \mathrm{L}\right.$ and $2.00 \times 10^{3} / \mathrm{L}$, respectively). However, mild, moderate and sever lymphopenia featured in patients with COVID-19 infection (Groups 2-4) with lymphocyte count $\left(1.6 \times 10^{9} / \mathrm{L}, 1.2 \times 10^{9} / \mathrm{L}\right.$ and $1.0 \times 10^{9} / \mathrm{L}$, respectively) when compared with persons with negative test of COVID-19 infection (Group 1). On the other hand, milde moderate and sever eosinopenia featured in patients with COVID-19 infection (Groups 2-4) with eosinophil count $\left(1.8 \times 10^{3} / \mathrm{L}\right.$, $1.7 \times 10^{3} / \mathrm{L}$ and $1.5 \times 10^{3} / \mathrm{L}$, respectively) when compared with persons with negative test of COVID-19 infectious person (Group 1).

Table 2 showed serum ferritin as well as plasma C-reactive protein, and D-dimer levels of patients with COVID-19 compared to negative persons. Serum ferritin levels was significant increased in all patients with COVID-19 infection groups (2-4) when compared with persons with negative test of COVID-19 infection (Group 1) $(p<0.05)$. The levels of ferritin more pronounced in patients with acute infection than mild and moderate COVID-19 infectious patients. Also, normal levels of c-reactive protein and d-dimer in patients with mild infection. However, Plasma d-dimer levels was significant increased in patients with moderate and acute COVID-19 infection, groups ( 3 and 4) when compared with persons with negative test of COVID-19 infection (Group 1) $(p<0.05)$. The levels of $d$-dimer more pronounced in patients with acute infection than moderate COVID-19 infectious patients.

Table 3 showed phospholipids, total cholesterol, triacylglycerols, high density lipoprotein-cholesterol (HDL-C) and low density lipoprotein-cholesterol (LDL-C) levels of patients with COVID-19 compared to negative persons. All patients in groups ( 2 and 3 ) had a normal levels of phospholipids, total cholesterol, triacylglycerols, high density lipoprotein-cholesterol (HDL-C) and low density lipoprotein-cholesterol (LDLC) levels of patients with COVID-19 when compared to negative persons. However, levels of plasma 
phospholipids, cholesterol, HDL-C and LDL-C of patients with acute COVID-19 infection were significant decreased when compared to negative persons. Also, plasma triacylglycerols of patients with acute COVID-19 infection were significant increase when compared to negative persons.

Table 4 showed plasma sPLA2 activity as well as tumor necrosis factor (TNF)-a, interleukin (IL)-1 $\beta$, interleukin (IL)- 6 and interleukin IL-13 levels of patients with COVID-19 compared to negative persons. All patients in group (2) had a normal levels of plasma sPLA2 activity as well as TNF-a, IL-1ß, IL-6 and IL-13 in patient with mild COVID-19 infection when compared to negative persons. On the other hand, plasma sPLA2, TNF- $\alpha$, IL-1 $\beta$, IL- 6 and IL-13 of patients with moderate and acute COVID-19 infection (groups 3 and 4) were significant increase when compared to negative persons.

Our data in table 5 showed that significant correlation between plasma phospholipids and SPLA2 activity as well as TNF- $a$, IL-1 $\beta$, IL- 6 and IL-13.

\section{Clinical characteristics of normal person as well as patients with mild, moderate, and acute COVID-19 infection.}

- Figure 1: showed normal CT study of the chest (group 1, healthy person).

- Figure 2: showed bilateral peripheral ground glass opacities, suggested as mild COVID-19 infection (group 2).

- Figure 3: showed moderately bilateral ground glass infection of COVID-19 (Group 3).

- Figure 4: showed extensive bilateral ground glass infiltration of viral bronchopneumonia. Most probably COVID-19 (Group 4).

Clinical characteristics of healthy normal person and patients with COVID-19 pneumonia listed in Table 6. 11 healthy person and 34 patients with COVID-19 infection, were male and the mean age was $45 \pm 6$ years old. 34 (100\%) patients had not any underlying diseases, including diabetes mellitus, hypertension, renal, liver and coronary heart diseases. For the symptoms, $5(45.4 \%)$ of normal healthy persons as well as $12(80 \%)$ mild, $9(90 \%)$ moderate and $7(77.7 \%)$ severe patients with COVID-19 infection had fever (ranged from $37.5^{\circ} \mathrm{C}$ to $39.3^{\circ} \mathrm{C}$ ). Also, $2(18.1 \%)$ of normal healthy persons as well as $10(66.6 \%)$ mild, $7(70 \%)$ moderate, $8(80 \%)$ severe patients with COVID-19 infection had cough. However, $0(0.0 \%)$ of normal healthy persons as well as $6(40 \%)$ mild, $4(40 \%)$ moderate, $5(55.5 \%)$ severe patients with COVID-19 infection had diarrhea. In addition, $0(0.0 \%)$ of normal healthy persons as well as $4(26.6 \%)$ mild, $6(60 \%)$ moderate, $9(100 \%)$ severe patients with COVID-19 infection had chest tightness. On the other hand, $0(0.0 \%)$ of normal healthy persons as well as $12(80 \%)$ mild, $3(30 \%)$ moderate, $3(33.3 \%)$ severe patients with COVID-19 infection had dry mouth. Finally, $0(0.0 \%)$ of normal healthy persons as well as $14(93.3 \%)$ mild, $9(90 \%)$ moderate, $9(100 \%)$ severe patients with COVID-19 infection had fatigue.

CT findings of 11 healthy person and 34 patients with COVID-19 was listed in Table 7.

CT findings showed that $0(0.0 \%)$ of normal healthy persons as well as $15(100 \%)$ mild, $10(100 \%)$ moderate, 9(100\%) severe patients with COVID-19 infection had ground glass opacity (GGO). Also, 
$0(0.0 \%)$ of normal healthy persons as well as $0(0.0 \%)$ mild, $5(50 \%)$ moderate, $9(100 \%)$ severe patients with COVID-19 infection had consolidation. However, $0(0.0 \%)$ of normal healthy persons as well as 0 $(0.0 \%)$ mild, $2(20 \%)$ moderate, $4(44.4 \%)$ severe patients with COVID-19 infection had vascular perforator sign. In addition, $0(0.0 \%)$ of normal healthy persons as well as $10(66.6 \%)$ mild, $5(50 \%)$ moderate, $5(55.5 \%)$ severe patients with COVID-19 infection had right lung predominant. On the other hand, $0(0.0 \%)$ of normal healthy persons as well as $1(6.6 \%)$ mild, $2(20 \%)$ moderate, $1(11.1 \%)$ severe patients with COVID-19 infection had left lung predominant. The results of our study showed that, $0(0.0 \%)$ of normal healthy persons as well as $15(33.3 \%)$ mild, $3(30 \%)$ moderate, $3(33.3 \%)$ severe patients with COVID-19 infection had upper lung predominant. However, $0(0.0 \%)$ of normal healthy persons as well as $10(66.6 \%)$ mild, $7(70 \%)$ moderate, $6(66.6 \%)$ severe patients with COVID-19 infection had lower lung predominant. Also, $0(0.0 \%)$ of normal healthy persons as well as $15(100 \%)$ mild, $10(100 \%)$ moderate, $9(100 \%)$ severe patients with COVID-19 infection had Peripheral lung predominant. In addition, $0(0.0 \%)$ of normal healthy persons as well as $2(13.3 \%)$ mild, $1(10 \%)$ moderate, $0(0)$ severe patients with COVID-19 infection had unilateral predominant. Finally, $0(0.0 \%)$ of normal healthy persons as well as $13(86.6 \%)$ mild, $9(90 \%)$ moderate, $9(100 \%)$ severe patients with COVID-19 infection had bilateral predominant.

\section{Discussion}

Coronaviruses are a large family of viruses that cause disease ranging from common cold to more serious diseases, such as Middle East Respiratory Syndrome (MERS-CoV) and Severe Acute Respiratory Syndrome (SARS-CoV). A novel coronavirus ( $\mathrm{nCoV}$ ) is a new strain not previously discovered in humans [39]. COVID-19 genome contains $15 \mathrm{nsps}$, nsp1-nsp10 and nsp12-16, and 8 accessory proteins (3a, 3b, p6, $7 \mathrm{a}, 7 \mathrm{~b}, 8 \mathrm{~b}, 9 \mathrm{~b}$ and/or $\mathrm{f} 14$ ) [40]. All those proteins play a functional role in viral replication [41]. Our results showed that the detection of COVID-19 infections was concentrated between February 9 and July 13, 2020 and peaked. The diagnosis depends on 3 factors:

- The presence of significant respiratory illness: fever with dry cough, fatigue or difficulty breathing.

- Measurement of COVID-19 lgG/lgM Rapid Test Kit, Abbexa, Cambridge, United Kingdom).

- Lung CT diagnosis using syngo. CT DE Lung Analysis - Siemens Healthineers Global, Germany. The patients were classified according to the degree of severity into 3 groups mild, moderate and sever COVID-19 infection plus the first group of healthy persons with negative test for COVID-19 infection tests.

The present results showed that a significant difference in hematology indices between COVID-19positive and COVID-19-negative patients. The hematology indices in the present study indicated that the proportion of leukopenia, lymphopenia and eosinophil changes was higher among mild, moderate and sever patients with COVID-19 infection.

Our results are confirmed with the results of Zhang et al., [42] who reported that the patients infected with COVID-19 showed a decrease in leukocyte, lymphocyte and eosinophil count. 
Also, our result showed a significant increase in ferritin, C-reactive protein and d-dimer levels in patients who tested positive for COVID-19. Hyperferritinemia in the present study as a known factor of inflammation was in confirmed with Connelly et al. [43] who investigated serum ferritin levels in patients at risk for and with ARDS and found serum ferritin to be a predictor of ARDS. Also, patients critically ill with coronavirus disease-2019 (COVID-19) feature hyperinflammation, and the associated biomarkers (ferritin, C-reactive protein, and d-dimer) may be beneficial for risk stratification [44].

This finding supports the hypothesis that severe acute respiratory syndrome coronavirus [45] (SARS-CoV2) infection could induce the dysfunction of the hemostatic system, leading to a hypercoagulable state $[46,47]$. Recent evidence of lung pathology dissection has shown occlusion and micro-thrombosis formation in pulmonary small vessels of patients critically ill with COVID-19 [48]. Also, CRP is an acute phase inflammatory protein produced by the liver that may be elevated in several conditions, such as inflammation, cardiovascular disease, and infection [46].

These results showed that decreased plasma phospholipids, total cholesterol, HDL-C and LDL-C levels as well as significantly plasma triacyclglycerols increased were associated with an increased inflammation by severe COVID-19 infection. Patients with a variety of different infections (gram positive bacterial, gram negative bacterial, viral, tuberculosis) have similar alterations in plasma lipid levels. Specifically, total cholesterol, LDL cholesterol, and HDL cholesterol levels are decreased while plasma triglyceride levels are elevated or inappropriately normal for the poor nutritional status [47-51].

Also, we observed a striking decrease of phospholipid concentrations in patients with severe COVID-19 infection. The statistical analysis clearly showed that this is a reflection of systemic inflammation. There are different mechanisms to explain this downregulation. Firstly, it has been suggested that phospholipids can bind to acute phase reactants including CRP [52], which increased significantly in patient with severe COVID-19 infection in the present study. Also, the results of phospholipids, d-dimer and CRP as well as cytokines levels were supported to each other. Secondly, PCs can be hydrolyzed by phospholipase A2 in patients with severe COVID-19 infection [25] releasing one fatty acid and a lysoPC, which can then be hydrolyzed by lysophospholipase to yield another free fatty acid.

PLA2's enzymatic function is hydrolysis of phospholipids into free fatty acids, and lysophospholipids. Arachidonic acid (AA) is the free fatty acid in the phospholipid target's sn-2 position, the release of AA from phospholipids can then be transferred to eicosanoids [53] includes prostaglandins (PGs), leukotrienes (LTs), hepoxilins, and lipoxins (LXs), as well as several others synthesized by the actions of lipoxygenases and cycloxygenases on the common substratum, AA [54]. Eicosanoids such as leukotriene LTB4 and hepoxiline HXA3 serve as chemoattractants for neutrophils, playing a key role in the inflammatory process. On the other hand, PGs, like PGE2, and LXs, such as LXA4, can protect against excessive lung inflammation and participate in repairing lung tissue [55 and 56].

Our study suggested that the oxidation of phospholipid side chains during oxidative stress and inflammation by COVID-19 infection, polyunsaturated fatty acid side chains of membrane phospholipids 
can be modified by oxidation. Also, the significant alteration of plasma cholesterol, triacylglycerols, HDLC, LDL-C, CRP, d-dimer, sPLA and cytokines supports this suggestion.

Also, tumor necrosis factor (TNF)-a, interleukin (IL)-1ß, interleukin (IL)-6 and interleukin IL-13 levels of patients with COVID-19 compared to negative persons.

In the systemic hyperinflammation phase of COVID-19 proposed by Siddiqi and Mehra,[57] there is a significant elevation of inflammatory cytokines and biomarkers, such as interleukin (IL)-2, IL-6, IL-7, granulocyte-colony stimulating factor, macrophage inflammatory protein $1-a$, tumor necrosis factor-a (TNF-a), CRP, ferritin, and D-dimer. This stage consists of the most severe manifestation of the cytokine storm, in which excessive hyperinflammation may lead to cardiopulmonary collapse and multi-organ failure [57 and 58].

Cytokines are small, biologically highly active proteins that regulate the growth, function, and differentiation of cells and help steer the immune response and inflammation [59]. The previous studies demonstrated a significant increase in pro-inflammatory cytokines (IFNa, IFNy, IL-1 $\beta$, IL-6, IL-12, IL-18, IL33, TNFa, TGF 3 ) and chemokines (CXCL10, CXCL8, CXCL9, CCL2, CCL3, CCL5) precipitates and sustains the aberrant systemic inflammatory response [60-63]. The cytokine storm is readily followed by the immune system "attacking" the body, which in turn will cause ARDS and multiple organ failure, the final result being death, at least in the most severe cases of SARS-CoV-2 infection [64]. pro-inflammatory cytokines (IFNa, IFNy, IL-1 $\beta$, IL-6, IL-12, IL-18, IL-33, TNFa, TGF $\beta$ ) and chemokines (CXCL10, CXCL8, CXCL9, CCL2, CCL3, CCL5) precipitates and sustains the aberrant systemic inflammatory response [6063]. The cytokine storm is readily followed by the immune system "attacking" the body, which in turn will cause ARDS and multiple organ failure, the final result being death, at least in the most severe cases of SARS-CoV-2 infection [64].

For the present symptoms (fever, diarrhea and dry mouth), of our patients is case depended and increases in order form mild to severe COVID-19 infection. These suggests that fever and dry mouth may be the most important signs for the clinical pre-examination and triage of COVID-19 pneumonia [65]. However, it has been reported that even the portion is small, some patients with COVID-19 pneumonia may present non-respiratory symptoms [66], and these patients may be miss-diagnosed or be misdiagnosed. Therefore, under current epidemiological conditions, the physicians in the front line must be very vigilant and arrange chest HRCT imaging and virological testing in time.

Also, COVID-19 pneumonia patients, most of the pulmonary lesions involved bilaterally with multiple lung lobes, with a predominant distribution in the lower and peripheral part of the lungs, but this rarely involved unilaterally. These lesions were mainly distributed in the bilateral subpleural and basilar lung regions because these were blocked by the pleural surface and progressed along the pleural surface. Mainly the diameter of the lesions was approximately parallel to the pleura, and perpendicular to the bronchovascular bundles. Viruses in the same family share a similar pathogenesis and presentation, peripheral predominance lung involvement has also been observed in patients with SARS and MERS [67 and 70]. The most common HRCT findings were pure GGO, GGO with interlobular septal thickening, and 
mixed GGO with consolidation, while no complete consolidation was found in our patients. Furthermore, we also found nodules, including solid nodules and solid nodules surrounded by a halo and linear opacities in some patients. Each patient may have two or more types of opacity lesions, but the majority of the lesions were GGO. Studies have reported that COVID-19 pneumonia is a viral interstitial pneumonia, and the early stage of pathogenesis is type II alveolar epithelial cell injury, edema, proteinaceous exudate, and focal hyperplasia of pneumocytes with only patchy inflammatory cellular infiltration, which all presented by GGO on HRCT results [67-70]. With the further thickening of the reticular and/or interlobular septa might be shown, the density of the GGO would increase, typical crazy paving signs may appear, and local vascular congestion swelling could be observed in some lesions. however, Huang et al. reported that pleural effusion may be an indication of severe COVID-19 pneumonia [71], further study is required for the clarification of the discrepancy.

Our study suggested that, COVID-19 firstly seize host cell intracellular membranes to create new compartments known as double-membrane vesicles (DMVs) needed for viral genome amplification. A specific phospholipid composition is required by different viruses to form the perfect replicative organelles that are suitable for their replication [72]. DMVs are membranous structures that contain viral proteins and an array of confiscated host factors, which jointly orchestrate an exclusive lipid microenvironment ideal for coronavirus replication [73]. Cytosolic phospholipase A2a enzyme (CPLA2a) is critical for DMVs' formation and coronaviruses' replication [74]. Our study shows that, over expression of cPLA2 caused by COVID-19 infection (figure I). CPLA2 promotes gene expression of cytokine storm (TNFa, IL-1 3 , IL-6 and IL-13) which led to elevates the activity of sPLA2. Also, Phosphatidylglycerol depletion and cleavage of fatty acids esterified as well as enhance inflammation and lung damage caused by sPLA2 over expression. Our proposal has not been reported earlier to our knowledge, and this study is perhaps the first observation of its kind.

Phospholipids is synthesized by alveolar type 2 cells (T2C) to reduce the surface tension of alveolar cell membrane [75]. Phosphatidylglycerol (PG) and phosphatidylinositol (PI) participate in the packaging and extracellular organization of the phospholipids complex, as well as in immunomodulation and host defense [76-78].

In this study, we hypothesized that patients with COVID-19 develop chronic alterations of phospholipids levels and homeostasis that persist after severe infection.

Patients with severe COVID-19 infection showed significant alterations in their cytokines storm levels and exhibited an overall decrease in alveolar phospholipids availability that directly correlated with decreased pulmonary function.

\section{Conclusion}

COVID-19 have been known to the scientific community recently. We did not find any study about plasma levels of phospholipids and it's correlation with SPLA2 activity as well as tumor necrosis factor (TNF)-a, interleukin (IL)-1 $\beta$, interleukin (IL)- 6 and interleukin IL-13 to assess COVID-19 severity and this study is 
perhaps the first observation of its kind. The present study explains clearly depletion of plasma phospholipids as well as elevation of plasma SPLA2 activity and cytokines levels in patients with severs COVID-19 infection leads to alveolar epithelial cells injury alveolar collapse at expiration. The results of CT findings of 11 healthy person and 34 patients with COVID-19 were supported the plasma levels of phospholipids and cytokines. Based on current knowledge, the "cytokine storm" appears as one of the most dangerous and potentially life-threatening event related to COVID-19 sustaining its major clinical consequences. Clearly, the present study hypothesized that the patients with COVID-19 infection and characterized by dramatic depletion of plasma phospholipids may be need to surfactant replacement therapy to treat respiratory distress syndrome by COVID-19 and help to maintain the interconnected surfactant structures.

\section{Declarations}

\section{Ethics approval and consent to participate}

Ethical approval for the data collection was granted by the Research Ethics Committee at Shobra health insurance hospital. The present data were collected from the routine biochemical analysis and CT imaging examination for patients with mild, moderate and sever COVID-19 infection. Also, the present work was carried out to suggest a convenient mechanism for COVID-19 severity and explain it's correlation with the plasma levels of phospholipids and sPLA2a as well as cytokines storm.

\section{Consent for Publication}

The authors gave consent for their data to be used in the article

\section{Availability of data and materials}

Supporting data will be made available as it contains CT imaging and analytical data normal persons as well as mild, moderate and sever COVID-19 patients to study the correlation between disease severity and plasma levels of phospholipids and sPLA2a as well as cytokines storm

\section{Competing interests}

The authors declare no conflict of interest, financial or otherwise.

\section{Funding}

The authors are not currently in receipt of any research funding.

\section{Authors' contributions}

Experimental design of the present study was carried out by all authors. All participants in this study satisfied the following inclusion criteria: i) Proven diagnosis of COVID-19 infection or benign disease by Prof Dr. Noor Eldin Mohamed Ismail, Chest diseases consultant, Shobra health insurance hospital and Dr. 
Yasser O. Mosaad, Department of Pharmacy Practice \& Clinical Pharmacy, Faculty of Pharmaceutical sciences \& Pharmaceutical Industries. Biochemical analysis was carried out by Prof. Ali A. Ali, Prof. Rita M. Borik and Prof. Mohammed Abdalla Hussein. CT imaging and its reports was carried out by Dr. Ahmed $\mathrm{H}$. Mohamed. Wrote the protocol, wrote the first draft of the manuscript, managed the analyses of the study, managed the literature searches was carried out in collaboration between all authors. All authors read and approved the final manuscript

\section{Acknowledgements}

Declared none

\section{References}

1. Lu H, Stratton CW, Tang YW. (2020) Outbreak of pneumonia of unknown etiology in Wuhan, China: The mystery and the miracle. J. Med. Virol. 92, 401-402.

2. Huang C, Wang Y, Li Z, Ren L, Zhao J, Hu Y, Zhang L, Fan G, Xu J, Gu X. (2020). Clinical features of patients infected with 2019 novel coronavirus in Wuhan, China. Lancet 2020, 395, 497-506.

3. Guan WJ, Ni ZY, Hu Y, Liang WH, Ou CQ, He JX. (2020). Clinical characteristics of coronavirus disease 2019 in China. N Engl J Med, 382(18):1708-20.

4. World Health Organization Director-General's Opening Remarks at the Media Briefing on COVID-1911 March 2020. Available online: https://www.who.int/dg/speeches/detail/who-director-general-sopeningremarks-at-the-media-briefing-on-covid-19--11-march-2020 (accessed on 11 March 2020).

5. World Health Organization Director-General's Opening Remarks at the Media Briefing on COVID-19July 14, 2020. Available online: https://www.worldometers.info/coronavirus/? utm_campaign=homeAdUOA?Si

6. World Health Organization Director-General's Opening Remarks at the Media Briefing on COVID-19from Feb 14 to 9:44am CEST, 14 July 2020. Available online: https://covid19.who.int/region/emro/country/eg

7. World Health Organization Director-General's Opening Remarks at the Media Briefing on COVID-1925 May 2020. Available online: https://www.who.int/health-topics/coronavirus\#tab=tab_1.

8. Mehta P, McAuley DF, Brown M, Sanchez E, Tattersall RS, Manson JJ, (2020). COVID-19: consider cytokine storm syndromes and immunosuppression. Lancet, 395 (10229):1033-4.

9. Stebbing J, Phelan A, Griffın I, Tucker C, Oechsle O, Smith D. (2020). COVID-19: combining antiviral and anti-inflammatory treatments. Lancet Infect Dis, 20(4):400-2.

10. Tay MZ, Poh CM, Renia L, MacAry PA, Ng LFP. (2020). The trinity of COVID-19: immunity, inflammation and intervention. Nat Rev Immunol;1-12.

11. Wu C, Chen X, Cai Y, Xia J, Zhou X, Xu S, (2020). Risk factors associated with acute respiratory distress syndrome and death in patients with coronavirus disease 2019 pneumonia in Wuhan, China. JAMA Intern Med, 180(7):934-943. 
12. Cheng K, Wei M, Shen H, Wu C, Chen D, Xiong W. (2020) Clinical characteristics of 463 patients with common and severe type coronavirus disease (In Chinese). Shanghai Med J, 1-15.

13. Gao Y, Li T, Han M, Li X, Wu D, Xu Y. (2020). Diagnostic utility of clinical laboratory data determinations for patients with the severe COVID-19. J Med Virol, 92(7):791-796.

14. Qin C, Zhou L, Hu Z, Zhang S, Yang S, Tao Y. (2020). Dysregulation of immune response in patients with COVID-19 in Wuhan, China. Clin Infect Dis, doi: 10.1093/cid/ciaa248.

15. Xiao K, Shui L, Pang X, Mu H, Wang J, Lang C. (2020). The clinical features of the 143 patients with COVID-19 in North-East of Chongqing (In Chinese). J Third Mil Med Univ;1-5.

16. Rooney SA, Young SL, Mendelson CR. (1994). Molecular and cellular processing of lung surfactant. FASEB J. 8: 957-967.

17. Schmidt R, Markart P, Ruppert C, Wygrecka M, Kuchenbuch T, Walmrath D, Seeger W, Guenther A. (2007). Time-dependent changes in pulmonary surfactant function and composition in acute respiratory distress syndrome due to pneumonia or aspiration. Respir Res. 8:55-64.

18. Mingarro I, Lukovic D, Vilar M, Perez-Gil J. (2008). Synthetic pulmonary surfactant preparations: new developments and future trends. Curr Med Chem. 15:393-403.

19. Numata M, Voelker DR. (2010). Asthma and infections. In: Martin RJ, Sutherland ER, editors. Lung biology in health and disease. New York: Informa Healthcare. pp. 45-165.

20. Wright SM, Hockey PM, Enhorning G, Strong P, Reid KB, Holgate ST, Djukanovic R, Postle AD. (2000). Altered airway surfactant phospholipid composition and reduced lung function in asthma. J Appl Physiol, 89:1283-1292.

21. Kuronuma K, Mitsuzawa H, Takeda K, Nishitani C, Chan ED, Kuroki Y, Nakamura M, Voelker DR. (2009). Anionic pulmonary surfactant phospholipids inhibit inflammatory responses from alveolar macrophages and U937 cells by binding the lipopolysaccharideinteracting proteins CD14 and MD-2. J Biol Chem, 284: 25488-25500.

22. Zhang K, Phan SH. (1996). Cytokines and pulmonary fibrosis. Biol Signals, 5:232-9.

23. Sullivan LC, Orgeig S, Daniels CB. (2002). Control of the development of the pulmonary surfactant system in the saltwater crocodile, Crocodylus porosus. Am J Physiol Regul Integr Comp Physiol. 283(5):R1164-76.

24. Crouch E, Wright JR. (2001). Surfactant proteins a and d and pulmonary host defense. Annu Rev Physiol. 63:521-54

25. Hussein MA. (2020). Administration of exogenous phospholipid surfactant and cytosolic phospholipase A2a inhibitors may help COVID-19 infected patients with chronic disease to remove inflammatory mediators, improve oxygenation and lung mechanics and prevent creation of infectious virus progeny: more is better. Coronaviruses Journal. In published.

26. Triggiani M, Granata F, Giannattasio G. (2005) Secretory phospholipases A2 in inflammatory and allergic diseases: not just enzymes. J Allergy Clin Immunol 116:1000-6. 
27. Perrin-Cocon L, Agaugue S, Coutant F. (2004). Secretory phospholipase A2 induces dendritic cell maturation. Eur J Immunol, 34:2293-302.

28. Ramoner R, Putz T, Gander H. (2005). Dendritic-cell activation by secretory phospholipase A2. Blood, 105:3583-7.

29. Tessier C, Hichami A, Khan NA. (2002). Implication of three isoforms of PLA(2) in human Tcell proliferation. FEBS Lett. 520:111-16.

30. Triggiani M, Granata F, Oriente A. (2002). Secretory phospholipases A2 induce cytokine release from blood and synovial fluid monocytes. Eur J Immunol, 32:67-76.

31. Triggiani M, Granata F, Balestrieri B. (2003). Secretory phospholipases A2 activate selective functions in human eosinophils. J Immunol. 170:3279-88.

32. Jo EJ, Lee HY, Lee YN. (2004). Group IB secretory phospholipase A2 stimulates CXC chemokine ligand 8 production via ERK and NF-kappa B in human neutrophils. J Immunol,173:6433-9.

33. Granata F, Petraroli A, Boilard E. (2005). Activation of cytokine production by secreted phospholipase $\mathrm{A} 2$ in human lung macrophages expressing the M-type receptor. J Immunol, 174:464-74.

34. Mehmet S, Gökhan K, Pamir A, Fehmi T, Işık A, Servet K. (2020). Cytokine storm in COVID-19: pathogenesis and overview of anti-inflammatory agents used in treatment. Clinical Rheumatology. 39:2085-2094.

35. Hulkower KI, Wertheimer SJ, Levin W, Coffey JW, Anderson CM, Chen T, DeWitt DL, Crowl RM, Hope WC, Morgan DW. (1994). Interleukin-1 induces cytosolic phospholipase A2 and prostaglandin H synthase in rheumatoid synovial fibroblasts. Evidence for their roles in the production of prostaglandin E2. Arthritis Rheum 37: 653-661.

36. Van P, V, Refaat Z, Dessev C, Blaine S, Wick M, Butterfield L, Han SY, Heasley LE, Nemenoff RA. (2001). Induction of cytosolic phospholipase A2 by oncogenic Ras is mediated through the JNK and ERK pathways in rat epithelial cells. J Biol Chem 276: $1226-1232$.

37. Chuen-Mao Y, I-Ta L, Pei-L,1 Shin-E, Li-Der H, Chih-K. (2014). TNF- induces cytosolic phospholipase A2 expression via Jak2/PDGFR-dependent Elk-1/p300 activation in human lung epithelial cells. Am J Physiol Lung Cell Mol Physiol 306: L543-L551.

38. Petrovic N, Grove C, Langton PE. (2001) A simple assay for a human serum phospholipase A2 that is associated with high-density lipoproteins. J Lipid Res, 42:1706-13.

39. World Health Organization. About COVID-19 March 2020. Available online:

http://www.emro.who.int/health-topics/corona-virus/about-covid-19.html (accessed on Sunday 7th of June 2020 09:20:46 PM).

40. Wu A, Peng Y, Huang B, Ding X, Wang X, Niu P, Meng J, Zhu Z, Zhang Z, Wang J, Sheng J, Quan L, Xia $Z$, Tan W, Cheng G, Jiang T. (2020). Genome composition and divergence of the novel Coronavirus (2019-nCoV) originating in China. Cell Host Microbe S1931-3128(20)30072-X. doi: 10.1016/j.chom.2020.02.001.

41. Chen Y, Liu Q, Guo D. (2020). Emerging coronaviruses: genome structure, replication, and pathogenesis J Med Virol 10.1002/jmv.25681. doi:10.1002/jmv.25681. 
42. Zhang, JJ, Dong, Z, Cao, YY, Yuan, YD, Yang YB, Yan YQ. (2020). Clinical characteristics of 140 patients infected with SARS-CoV-2 in Wuhan, China, Allergy (2020), https://doi.org/10.1111/all.14238

43. Connelly KG, Moss M, Parsons PE, Moore EE, Moore FA, Giclas PC. (1997) Serum ferritin as a predictor of the acute respiratory distress syndrome. Am J Respir Crit Care Med. 1997; 155: 21-25.

44. Ian H, Raymond P, Michael A L,Amaylia O, Bachti A. (2020). C-reactive protein, procalcitonin, D-dimer, and ferritin in severe coronavirus disease-2019: a meta-analysis. Ther Adv Respir Dis. doi:

$10.1177 / 1753466620937175$.

45. Chen N, Zhou M, Dong X, et al. Epidemiological and clinical characteristics of 99 cases of 2019 novel coronavirus pneumonia in Wuhan, China: a descriptive study. Lancet2020; 395: 507-513.

46. Levi M, van der Poll T (2017). Coagulation and sepsis. Thromb Res; 149: 38-44.

47. Lin L, Lu L, Cao W. (2020). Hypothesis for potential pathogenesis of SARS-CoV-2 infection - a review of immune changes in patients with viral pneumonia. Emerg Microbes Infect, 1-14.

48. Lue W, Yu H, Gou J. (2020) Clinical pathology of critical patient with novel coronavirus pneumonia (COVID-19). Preprints, 1-18.

49. Sproston NR, Ashworth JJ. Role of C-reactive protein at sites of inflammation and infection. Front Immunol2018; 9: 1-11.

50. Khovidhunkit W, Kim MS, Memon RA, Shigenaga JK, Moser AH, Feingold KR, Grunfeld C. (2004) Effects of infection and inflammation on lipid and lipoprotein metabolism: mechanisms and consequences to the host. J Lipid Res. 45:1169-1196.

51. Gallin JI, Kaye D, O'Leary WM. (1969). Serum lipids in infection. N Engl J Med. 281:1081-1086.

52. van Leeuwen HJ, Heezius EC, Dallinga GM, van Strijp JA, Verhoef J, van Kessel KP. (2003).

Lipoprotein metabolism in patients with severe sepsis. Crit Care Med. 31:1359-1366.

53. Schwalbe RA, Dahlback B, Coe JE, Nelsestuen GL. (1992). Pentraxin family of proteins interact specifically with phosphorylcholine and/or phosphorylethanolamine. Biochemistry.31(20):4907-15.

54. Schaloske RH, Dennis E. (2006). The phospholipase A2 superfamily and its group numbering system. Biophys. Acta17611246-1259.

55. Serhan CN. (2007). Resolution phase of inflammation: novel endogenous anti-inflammatory and proresolving lipid mediators and pathways. Rev. Immunol.25101-137.

56. Vancheri C, Mastruzzo C, Sortino MA, Crimi N. (2004). The lung as a privileged site for the beneficial actions of PGE2. Trends Immunol.2540-46.

57. Siddiqi HK, Mehra MR. (2020). COVID-19 illness in native and immunosuppressed states: a clinicaltherapeutic staging proposal. J Heart Lung Transplant, 39: 405-407.

58. Zhang W, Zhao Y, Zhang F. (2020). The use of anti-inflammatory drugs in the treatment of people with severe coronavirus disease 2019 (COVID-19): the experience of clinical immunologists from China. Clin Immunol, 214: 108393.

59. Thomson A. The Cytokine Handbook. 3rd ed. New York, NY: Academic Press; 1998. 
60. Huang C, Wang Y, Li X, Ren L, Zhao J, Hu Y, Zhang L, Fan G, Xu J, Gu X, Cheng Z, Yu T,Xia J, Wei Y, Wu W, Xie X, Yin W, Li H, Liu M, Xiao Y, Gao H, Guo L, Xie J, Wang G, Jiang R, Gao Z, Jin Q, Wang J, Cao B. (2020), Clinical features of patients infected with 2019 novel coronavirus in Wuhan, China Lancet, 395; 497-506

61. Channappanavar R, Perlman S. (2017). Pathogenic human coronavirus infections: causes and consequences of cytokine storm and immunopathology Semin. Immunopathol., 39 (5): 529-539.

62. Cameron MJ, Bermejo-Martin JF, Danesh A, Muller MP, Kelvin DJ(2008). Human immunopathogenesis of severe acute respiratory syndrome (SARS) Virus Res., 133 (1); 13-19

63. Williams AE, R.C. Chambers RC. (2014). The mercurial nature of neutrophils: still an enigma in ARDS? J. Physiol. Lung Cell Mol. Physiol., 306 (3); L217-30.

64. Bhatia M, Zemans RL, Jeyaseelan S. (2012). Role of chemokines in the pathogenesis of acute lung injury Am. J. Respir. Cell Mol. Biol., 46 (5); 566-572

65. Zhou P, Yang XL, Wang XG, Hu B, Zhang L, Zhang W, et al. (2020) A pneumonia outbreak associated with a new coronavirus of probable bat origin. Nature, 579: 270-273.

66. Perlman S (2020) Another decade, another coronavirus. N Engl J Med, 382(8): 760-762.

67. Wang Q, Zhang ZY, Shi Y and Jiang Y (2013) Emerging H7N9 influenza A (novel reassortant avianorigin) pneumonia: radiologic findings. Radiology, 268(3): 882-889.

68. Koo HJ, Lim S, Choe J, Choi SH, Sung H, Do KH (2018) Radiographic and CT Features of Viral Pneumonia. Radiographics, 38(3): 719-739.

69. Xu Z, Shi L, Wang Y, Zhang J, Huang L, Zhang C, et al. (2020) Pathological findings of COVID-19 associated with acute respiratory distress syndrome. Lancet Respir Med, 2020 Feb 18. pii: S22132600(20)30076-X. doi: 10.1016/S2213-2600(20)30076-X.

70. Tian S, Hu W, Niu L, Liu H, Xu H, Xiao SY (2020) Pulmonary Pathology of Early Phase 2019 Novel Coronavirus (COVID19) Pneumonia in Two Patients with Lung Cancer. J Thorac Oncol, 2020 Feb 28. pii: S1556-0864(20)30132-5. doi: 10.1016/j.jtho.2020.02.010.

71. Huang L, Han R, Yu PX, Wang SK, Xia LM (2020) A correlation study of CT and clinical features of different clinical types of 2019 novel coronavirus pneumonia. Chin J Radiol, 54(00): E003-E0.

72. Knoops K, Kikkert M, Worm SH, Zevenhoven-Dobbe JC, van der Meer Y, Koster AJ, Mommaas AM, Snijder EJ. (2008). SARS-coronavirus replication is supported by a reticulovesicular network of modified endoplasmic reticulum. PLoS Biol, 6, e226.

73. Muller C, Hardt M, Schwudke D, Neuman BW, Pleschka S, Ziebuh (2018). Inhibition of Cytosolic Phospholipase A2alpha Impairs an Early Step of Coronavirus Replication in Cell Culture. J. Virol, 92104.

74. Schaloske RH, Dennis E. (2006). The phospholipase A2 superfamily and its group numbering system. Biophys. Acta17611246-1259.

75. Lopez-Rodriguez E, Perez-Gil J. (2014). Structure-function relationships in pulmonary surfactant membranes: from biophysics to therapy. Biochim Biophys Acta. 1838(6):1568-85. 
76. Fessler MB, Summer RS. (2016). Surfactant Lipids at the Host-Environment Interface. Metabolic Sensors, Suppressors, and Effectors of Inflammatory Lung Disease. Am J Respir Cell Mol Biol. 54(5):624-35.

77. Glasser JR, Mallampalli RK. (2012). Surfactant and its role in the pathobiology of pulmonary infection. Microbes Infect. 14(1):17-25.

78. Kuronuma K, Mitsuzawa H, Takeda K, Nishitani C, Chan ED, Kuroki Y. (2009). Anionic pulmonary surfactant phospholipids inhibit inflammatory responses from alveolar macrophages and U937 cells by binding the lipopolysaccharide-interacting proteins CD14 and MD-2. J Biol Chem. 2009; 284(38):25488-500.

\section{Tables}

Table 1: Hematological parameters of patients with COVID-19 compared to negative persons 


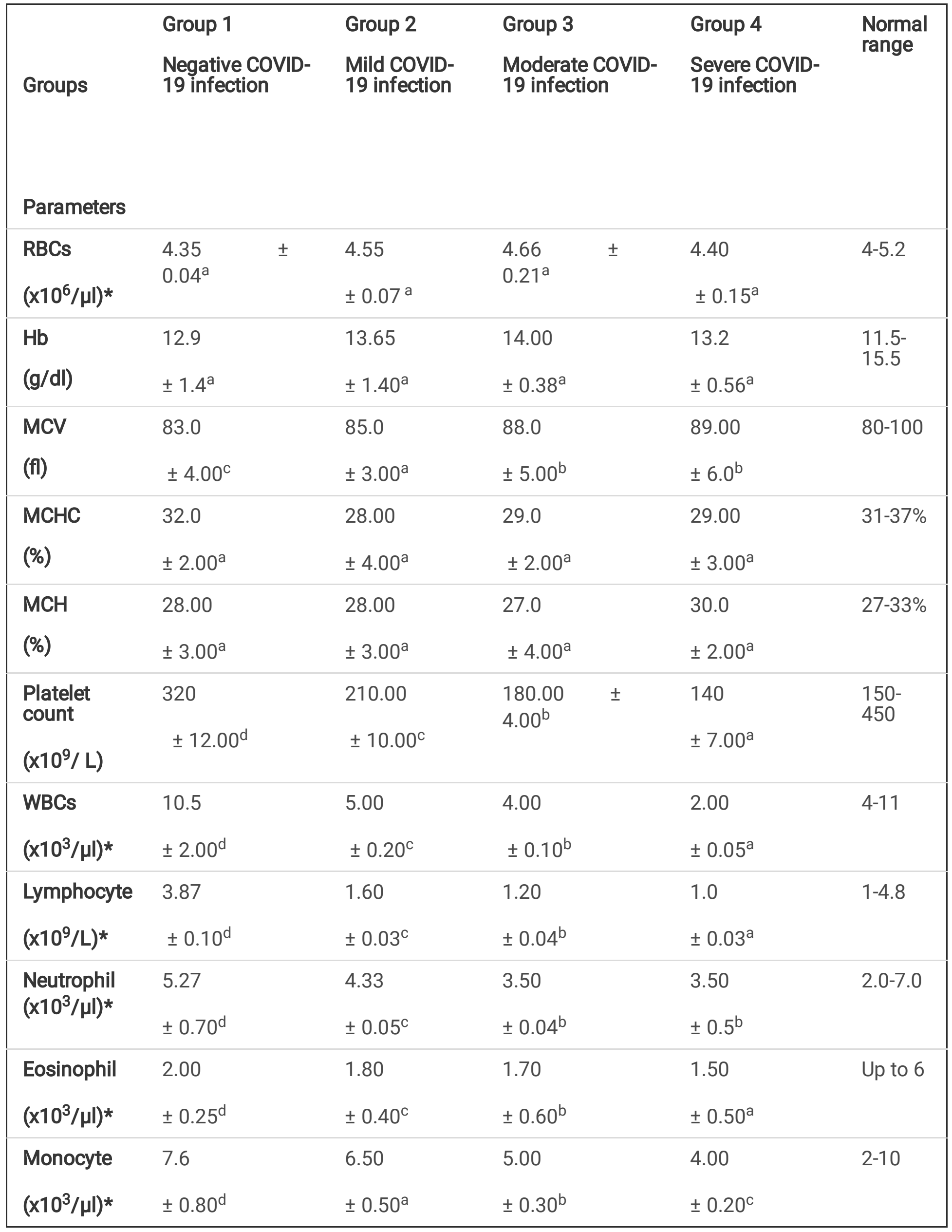


abcd Means with different superscript within same row are statistically different at level $\mathrm{P}<0.05$ according to Duncan's multiple range test

Table 2: Serum ferritin as well as plasma C-reactive protein, and D-dimer levels of patients with COVID-19 compared to negative persons

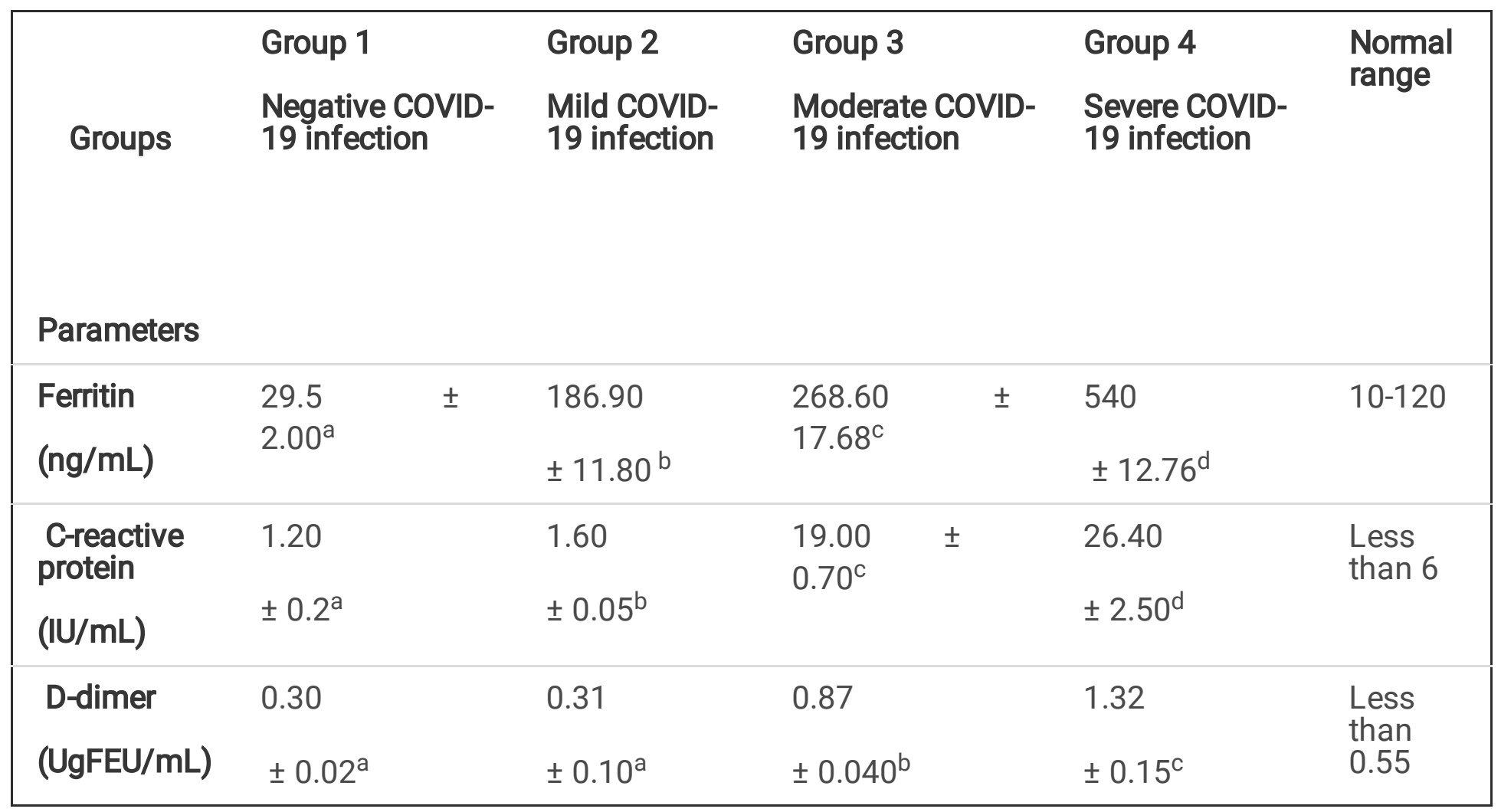

abcd Means with different superscript within same row are statistically different at level $\mathrm{P}<0.05$ according to Duncan's multiple range test

Table 3: Plasma phospholipids, total cholesterol, triacylglycerols, high density lipoprotein-cholesterol (HDL-C) and low density lipoprotein-cholesterol (LDL-C) levels of patients with COVID-19 compared to negative persons 


\begin{tabular}{|c|c|c|c|c|}
\hline Groups & $\begin{array}{l}\text { Group } 1 \\
\text { Negative COVID- } \\
19 \text { infection }\end{array}$ & $\begin{array}{l}\text { Group } 2 \\
\text { Mild COVID-19 } \\
\text { infection }\end{array}$ & $\begin{array}{l}\text { Group } 3 \\
\text { Moderate COVID- } \\
19 \text { infection }\end{array}$ & $\begin{array}{l}\text { Group } 4 \\
\text { Severe COVID-19 } \\
\text { infection }\end{array}$ \\
\hline Parameters & & & & \\
\hline $\begin{array}{l}\text { Phospholipids } \\
\text { (mg/dL) }\end{array}$ & $\begin{array}{ll}168.98 & \pm \\
7.60^{a} & \end{array}$ & $\begin{array}{l}170.80 \\
\pm 8.50^{b}\end{array}$ & $\begin{array}{l}175.0 \\
9.00^{\mathrm{a}}\end{array}$ & $\begin{array}{l}94.30 \\
\pm 6.54^{b}\end{array}$ \\
\hline $\begin{array}{l}\text { Total } \\
\text { cholesterol } \\
(\mathrm{mg} / \mathrm{dL})\end{array}$ & $\begin{array}{l}175.8 \\
\pm 4.80^{\mathrm{a}}\end{array}$ & $\begin{array}{r}172.15 \\
\pm 8.70^{\mathrm{a}}\end{array}$ & $\pm 6.50^{\mathrm{a}}$ & $\begin{array}{l}120.6 \\
\pm 11.25^{\mathrm{b}}\end{array}$ \\
\hline $\begin{array}{l}\text { Triacylglycerols } \\
(\mathrm{mg} / \mathrm{dL})\end{array}$ & $\begin{array}{l}97.65 \\
\pm 5.68^{a}\end{array}$ & $\begin{array}{l}99.0 \\
\pm 8.14^{\mathrm{a}}\end{array}$ & $\begin{array}{l}98.5 \\
\pm 5.69^{a}\end{array}$ & $\begin{array}{l}170.08 \\
\pm 10.33^{b}\end{array}$ \\
\hline $\begin{array}{l}\text { HDL-C } \\
(\mathrm{mg} / \mathrm{dL})\end{array}$ & $\begin{array}{l}47.87 \\
\pm 3.20^{a}\end{array}$ & $\begin{array}{l}46.00 \\
\pm 3.10^{a}\end{array}$ & $\begin{array}{l}45.3 \\
\pm 2.65^{a}\end{array}$ & $\begin{array}{l}35.99 \\
\pm 4.35^{\mathrm{b}}\end{array}$ \\
\hline $\begin{array}{l}\text { LDL-C } \\
(\mathrm{mg} / \mathrm{dL})\end{array}$ & $\begin{array}{l}108.4 \\
\pm 4.80^{\mathrm{a}}\end{array}$ & $\begin{array}{r}108.35 \\
\pm 5.98^{\mathrm{a}}\end{array}$ & $\begin{array}{r}112.48 \\
\pm 6.57^{\mathrm{a}}\end{array}$ & $\begin{array}{l}50.59 \\
\pm 4.87^{\mathrm{b}}\end{array}$ \\
\hline
\end{tabular}

abcd Means with different superscript within same row are statistically different at level $P<0.05$ according to Duncan's multiple range test. LDL-cholesterol levels were calculated by using the Friedewald formula [ LDL-C= Cholesterol - HDL-C- (1/5 Triacylglycerols)].

Table 4: Plasma sPLA2 activity as well as tumor necrosis factor (TNF)- $\alpha$, interleukin (IL)-1 $\beta$, interleukin (IL)-6 and interleukin IL-13 levels of patients with COVID-19 compared to negative persons 


\begin{tabular}{|c|c|c|c|c|}
\hline Groups & $\begin{array}{l}\text { Group } 1 \\
\text { Negative COVID-19 } \\
\text { infection }\end{array}$ & $\begin{array}{l}\text { Group } 2 \\
\text { Mild COVID-19 } \\
\text { infection }\end{array}$ & $\begin{array}{l}\text { Group } 3 \\
\text { Moderate COVID-19 } \\
\text { infection }\end{array}$ & $\begin{array}{l}\text { Group } 4 \\
\text { Severe COVID-19 } \\
\text { infection }\end{array}$ \\
\hline Paramete & & & & \\
\hline sPLA2 & 430.60 & 433.53 & 447.15 & 516.21 \\
\hline (U) & $\pm 8.94^{\mathrm{a}}$ & $\pm 12.5^{\mathrm{a}}$ & $\pm 10.60^{b}$ & $\pm 18.05^{c}$ \\
\hline $\begin{array}{l}\text { TNF-a } \\
(p g / m L)\end{array}$ & $\begin{array}{l}11.70 \\
2.06^{\mathrm{a}}\end{array}$ & $\begin{array}{l}12.46 \\
\pm 1.87^{a}\end{array}$ & $\pm 1.55^{\mathrm{c}}$ & $\begin{array}{l}27.15 \\
\pm 2.10^{b}\end{array}$ \\
\hline $\begin{array}{l}\text { IL-1及 } \\
(\mathrm{pg} / \mathrm{dL})\end{array}$ & $\begin{array}{l}1.31 \\
\pm 0.08^{\mathrm{a}}\end{array}$ & $\begin{array}{l}1.50 \\
\pm 0.15^{\mathrm{a}}\end{array}$ & $5.05 \pm 0.30^{c}$ & $\begin{array}{l}16.36 \\
\pm 2.11^{\mathrm{b}}\end{array}$ \\
\hline $\begin{array}{l}\text { IL-6 } \\
(\mathrm{pg} / \mathrm{dL})\end{array}$ & $\begin{array}{l}47.20 \\
\pm 4.11^{\mathrm{a}}\end{array}$ & $\begin{array}{l}49.17 \\
\pm 3.08^{\mathrm{a}}\end{array}$ & $\begin{array}{l}68.50 \\
\pm 6.73^{b}\end{array}$ & $\begin{array}{l}77.08 \\
\pm 4.60^{c}\end{array}$ \\
\hline $\begin{array}{l}\text { IL-13 } \\
\text { (pg/dL) }\end{array}$ & $\begin{array}{l}0.27 \\
\pm 3.20^{\mathrm{a}}\end{array}$ & $\begin{array}{l}0.34 \\
\pm 3.10^{\mathrm{a}}\end{array}$ & $\begin{array}{l}1.68 \\
\pm 2.65^{\mathrm{b}}\end{array}$ & $\begin{array}{l}3.57 \\
\pm 4.35^{\mathrm{c}}\end{array}$ \\
\hline
\end{tabular}

${ }^{a b c}$ Means with different superscript within same row are statistically different at level $P<0.05$ according to Duncan's multiple range test. A unit (U) of SPLA2 activity was defined as nmol of product formed by 1 $\mathrm{ml}$ of plasma in a $1 \mathrm{~h}$ incubation and was calculated as $\left[\left(\mathrm{OD}_{425 \mathrm{~nm}}-\mathrm{OD}_{600 \mathrm{~nm}}\right) \times 78.62 \times 25\right]$ where 78.62 is the nmol of product producing an $\mathrm{OD}_{425}$ of $1.0 \mathrm{in} 0.2 \mathrm{ml}$ and 25 is the correction factor for $20 \mathrm{ml}$ of plasma to $1 \mathrm{ml}$ and a $2 \mathrm{~h}$ incubation to $1 \mathrm{~h}$.

Table 5: Correlation among plasma phospholipids and SPLA2 activity as well as cytokines levels evaluated by the Spearman rank correlation of patients with severe COVID-19 infection 


\begin{tabular}{|c|c|c|c|c|c|c|c|}
\hline Parameters & Statistical values & Phospholipids & sPLA2 & TNF-a & IL-1 $\beta$ & IL-6 & IL-13 \\
\hline \multirow[t]{2}{*}{ Phospholipids } & $r$ & - & -0.37 & 0.20 & 0.34 & 0.17 & 0.50 \\
\hline & $\mathrm{p}$ & - & 0.16 & 0.65 & 0.23 & 0.30 & 0.19 \\
\hline \multirow[t]{2}{*}{ sPLA2 } & $r$ & 0.18 & -- & 0.16 & 0.04 & 022 & 0.60 \\
\hline & $\mathrm{p}$ & 0.40 & -- & 0.40 & 0.11 & 0.54 & 0.04 \\
\hline \multirow[t]{2}{*}{ TNF- $a$} & $r$ & 0.20 & 0.43 & - & 0.08 & 0.17 & 0.30 \\
\hline & $\mathrm{p}$ & -0.44 & 0.20 & - & 0.23 & 0.62 & 0.08 \\
\hline \multirow[t]{2}{*}{ IL-1 $\beta$} & $r$ & 0.36 & 0.15 & 0.47 & - & 0.14 & 0.26 \\
\hline & $\mathrm{p}$ & 0.46 & 0.38 & 0.23 & - & 0.30 & 0.42 \\
\hline \multirow[t]{2}{*}{ IL-6 } & $r$ & 0.19 & 0.50 & - & 0.53 & - & 0.16 \\
\hline & $\mathrm{p}$ & 0.22 & 0.36 & - & 0.41 & - & 0.09 \\
\hline \multirow[t]{2}{*}{ IL-13 } & $r$ & 0.77 & 0.43 & - & 0.33 & 0.71 & -- \\
\hline & $\mathrm{p}$ & 0.18 & 0.06 & - & 0.19 & 0.20 & - \\
\hline
\end{tabular}

Table 6: Clinical characteristics of 11 healthy person and 34 patients with COVID-19:

\begin{tabular}{|lllll|}
\hline Symptoms & Normal (11) & Mild (15) & Moderate (10) & Severe (9) \\
\hline Fever & $5(45.4 \%)$ & $12(80 \%)$ & $9(90 \%)$ & $7(77.7 \%)$ \\
\hline Cough & $2(18.1 \%)$ & $10(66.6 \%)$ & $7(70 \%)$ & $8(80 \%)$ \\
\hline Diarrhea & $0(0)$ & $6(40 \%)$ & $4(40 \%)$ & $5(55.5 \%)$ \\
\hline Chest tightness & $0(0)$ & $4(26.6 \%)$ & $6(60 \%)$ & $9(100 \%)$ \\
\hline Dry mouth & $0(0)$ & $12(80 \%)$ & $3(30 \%)$ & $3(33.3 \%)$ \\
\hline fatigue & $0(0)$ & $14(93.3 \%)$ & $9(90 \%)$ & $9(100 \%)$ \\
\hline
\end{tabular}

Table 7: CT findings of 11 healthy person and 34 patients with COVID-19: 


\begin{tabular}{|c|c|c|c|c|}
\hline CT findings & Normal (11) & Mild (15) & Moderate (10) & Severe (9) \\
\hline Ground glass opacity (GGO) & $0(0)$ & $15(100 \%)$ & $10(100 \%)$ & $9(100 \%)$ \\
\hline Consolidation & $0(0)$ & $0(0)$ & $5(50 \%)$ & $9(100 \%)$ \\
\hline Mixed GGO and consolidation & $0(0)$ & $0(0)$ & $5(50 \%)$ & $9(100 \%)$ \\
\hline Bronchial wall thickening & $0(0)$ & $0(0)$ & $1(10 \%)$ & $2(22.2 \%)$ \\
\hline Crazy paving sign & $0(0)$ & $1(1.5 \%)$ & $2(20 \%)$ & $5(55.5 \%)$ \\
\hline Air bronchogram & $0(0)$ & $1(1.5 \%)$ & $2(20 \%)$ & $6(66.6 \%)$ \\
\hline Vascular perforator sign & $0(0)$ & $0(0)$ & $2(20 \%)$ & $4(44.4 \%)$ \\
\hline Intrathoracic lymph node enlargement & $0(0)$ & $0(0)$ & $0(0)$ & $0(0)$ \\
\hline Pleural effusions & $0(0)$ & $0(0)$ & $0(0)$ & $0(0)$ \\
\hline \multicolumn{5}{|l|}{ Right/Left distribution } \\
\hline Right lung predominant & $0(0)$ & $10(66.6 \%)$ & $5(50 \%)$ & $5(55.5 \%)$ \\
\hline Left lung predominant & $0(0)$ & $1(6.6 \%)$ & $2(20 \%)$ & $1(11.1 \%)$ \\
\hline Equivalent in both lung & $0(0)$ & $4(66.6 \%)$ & $3(30 \%)$ & $3(33.3 \%)$ \\
\hline \multicolumn{5}{|l|}{ Craniocaudal distribution } \\
\hline Upper lung predominant & $0(0)$ & $5(33.3 \%)$ & $3(30 \%)$ & $3(33.3 \%)$ \\
\hline Lower lung predominant & $0(0)$ & $10(66.6 \%)$ & $7(70 \%)$ & $6(66.6 \%)$ \\
\hline \multicolumn{5}{|l|}{ Transverse distribution } \\
\hline Central & $0(0)$ & $0(0)$ & $0(0)$ & $0(0)$ \\
\hline Peripheral & $0(0)$ & $15(100 \%)$ & $10(100 \%)$ & $9(100 \%)$ \\
\hline \multicolumn{5}{|l|}{ Lung region distribution } \\
\hline Unilateral & $0(0)$ & $2(13.3 \%)$ & $1(10 \%)$ & $0(0)$ \\
\hline Bilateral & $0(0)$ & $13(86.6 \%)$ & $9(90 \%)$ & $9(100 \%)$ \\
\hline \multicolumn{5}{|l|}{ Scattering distribution } \\
\hline 1 & $0(0)$ & $1(6.6 \%)$ & $0(0)$ & 0 \\
\hline 2 & $0(0)$ & $2(13.3 \%)$ & $0(0)$ & $0(0)$ \\
\hline$\geq 3$ & $0(0)$ & $12(80 \%)$ & $9(100 \%)$ & $9(100 \%)$ \\
\hline
\end{tabular}


Figures

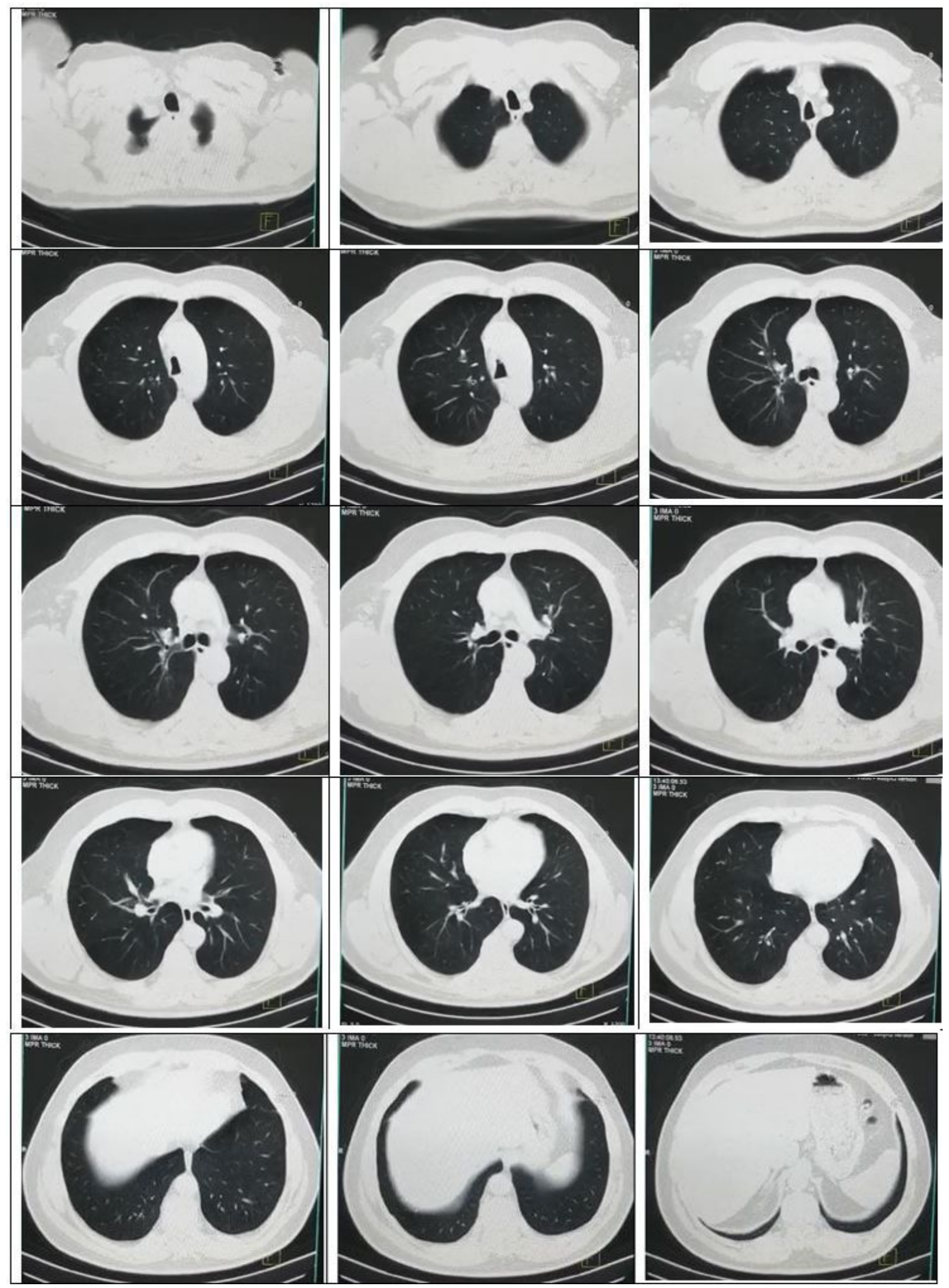

Figure 1

Normal CT study of the chest. 


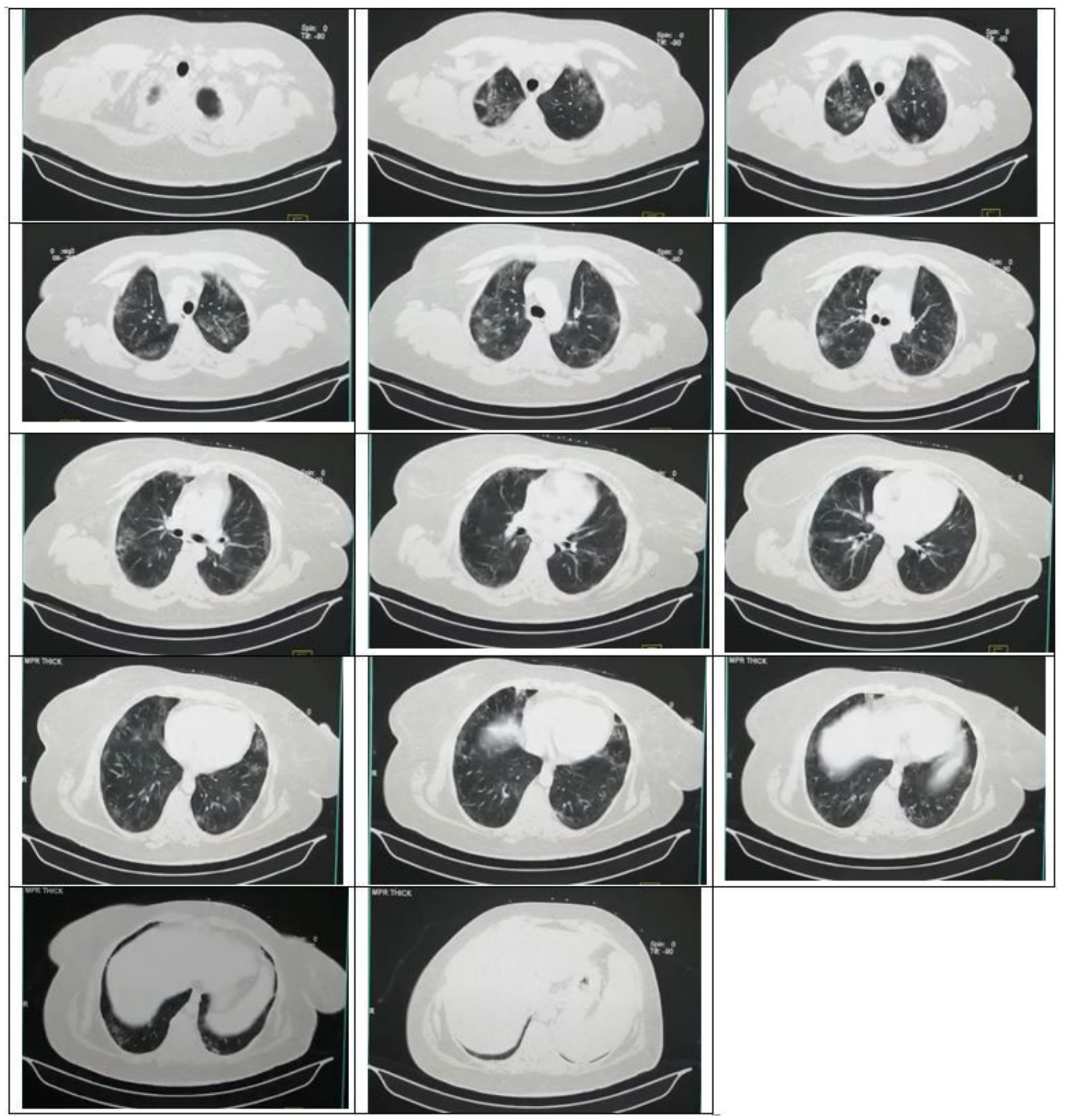

Figure 2

Bilateral areas of ground glass opacities with areas of ill-defined consolidation with exaggerated Broncho vascular markings as mild COVID-19 infection. 


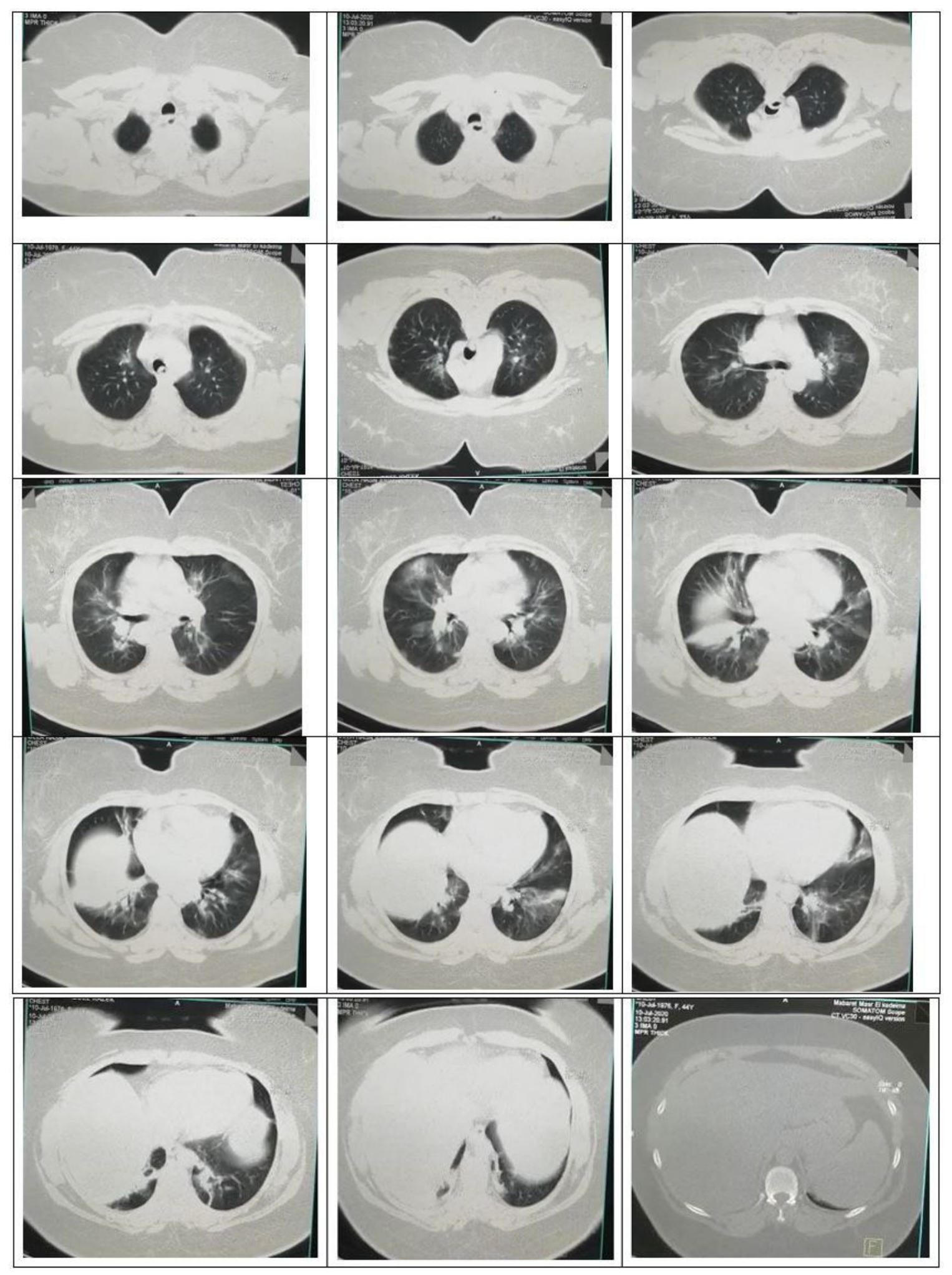

Figure 3

Showed multiple bilateral peripheral ground glassy appearance, suggested as moderate covid-19 infection. 


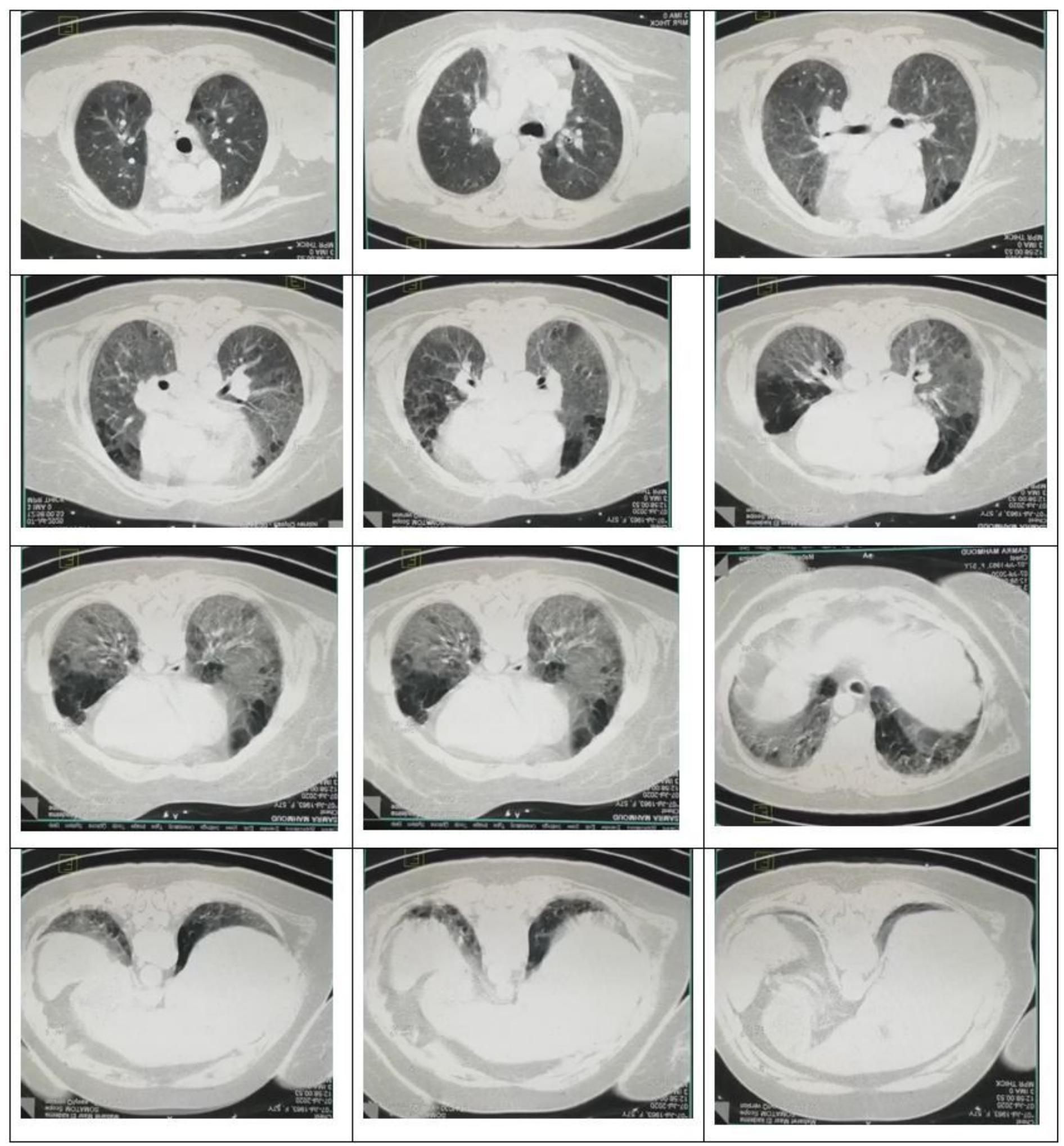

Figure 4

Diffuse lung parenchyma ground glass opacities involving almost of both lung lobes, suggested as sever COVID-19 infection. 